\title{
Agri-Horticultural Interventions for Doubling of Farmer's Income
}

\author{
L. C. De ${ }^{1 *}$, Tulipa De ${ }^{2}$, R. K. Pamarthi ${ }^{1}$ and R. K. Singh ${ }^{1}$ \\ ${ }^{1}$ ICAR-NRC for Orchids, Pakyong-737106, Sikkim, India \\ ${ }^{2}$ Department of Plant Pathology, UBKV, Pundibari, Cooch Behar, West Bengal, India \\ *Corresponding author
}

\section{Keywords \\ Agricultural productivity, Resource use efficiency}

\section{Article Info}

Accepted:

12 November 2019

Available Online:

10 December 2019

\section{A B S T R A C T}

Doubling farmers' income has emerged as the focal point for all the agricultural policy decision of the government due to increase in number of farmers suicide and low and high fluctuating farmers income. The Doubling farmers income is formulated by bridging the productivity gaps, employing latest production technologies, advanced processing technologies and improved marketing and feasible through effective land use planning, diversified farming systems, wasteland management, conservation agriculture and livestock management, climate resilient agriculture, rainfed agriculture, dry land farming, protected cultivation, modern nursery management techniques for improvement in agricultural productivity, resource use efficiency, increase in cropping intensity and diversification towards high value crops.

\section{Introduction}

India's population is expected to reach 1.7 billion by 2050, making it as the most populated country in the world. To feed the ever increasing population, food production must increase by $70 \%$.

This challenge is very critical because Indian agriculture is facing several challenges due to fragmentation of holdings, ill impact of climate change, sustaining investment, high fluctuation in prices and production, unorganized markets, erratic market behaviour, conversion of agricultural land for non-farm purposes and increased cost of production (Gangaiah, 2018).

The present context of the Indian agriculture sector revealed that the farmers are facing serious deficit of income which has become an important issue and as a result dissuading the rural youth to take up agriculture as livelihood mission.

The Doubling farmers income has become a slogan for every agricultural institution and is formulated by bridging the productivity gaps, 
employing latest production technologies, advanced processing technologies and improved marketing.

Why Double Farmers' Income (Saikia and Bordoloi, 2019)

Doubling farmers' income has emerged as the focal point for all the agricultural policy decision of the government due to the following reasons:

Income of the farmers is less than poverty line

Farmer's income is low as compared to the workers in non-farm sector

Increase in number of farmers suicide

Low and high fluctuating farmers income

Sources of Growth in Farmers' Income (Chand Ramesh, 2017)

According to Niti Aayog, the major sources of growth operating within agricultural sector are:

Improvement in agricultural productivity through timely supply of good quality of sufficient seeds and planting materials prior to season, timely availability of good quality of inputs, adoption of short duration high yielding varieties. Increase SRR of hybrid seeds, by promoting farm mechanization, application of Integrated Nutrient Management, application of Integrated Pest Management, by increasing irrigation facilities $\&$ enhancing water-use efficiency and adoption of DSR/Zero Tillage/SRI.

Resource use efficiency or saving in cost of production through subsidy on farm inputs, provision of subsidy on HYV/ hybrid variety of seeds in light of market price, subsidy on mechanization in light of market price, use of green manuring e.g. Dhaincha, Moong, Cowpea, Sunhemp etc., application of balance dose of fertilizer on the basis of soil health card, provision of subsidy on diesel, promotion of custom hiring system, use of bio fertilizers e.g. Rhizobium, PSB, Azotobactor, Azolla, Blue green Algae, Mycorrhiza, Subsidy of transport, use of gobar/bio gas, promotion of zero tillage technology, promotion of DSR, use of organic fertilizers and manure.

Increase in cropping intensity by prepared for Kharif, Rabi and Garma for 03 years

Paddy - wheat/pulses/Maize

Maize - Wheat/Pulses/Maize

Maize - Wheat/Pulses/Maize - Mung

Vegetable (cauliflower) - potato - onion mung

Maize/Vegetable - Potato-Potato-OnionMung

Paddy (short duration) - vegetable - onion maize

Paddy - vegetable - maize

Short duration hybrid/HYV seeds to be used.

Use of rice fallow land

Rice- Makhana cropping System

Diversification towards high value crops through

Introduction of new cultivated species and improved varieties of crops

Cash crops- Sugarcane, betel leaf, exotic fruits, ornamentals and vegetables 
Spices - Turmeric, ginger, dhania, garlic, ajwain and saunf

Mushroom Cultivation

Rearing of honey bee

\section{Role of agriculture sector}

Effective Agricultural Land Use Planning using soil resource inventory, agro technology transfer under Mera Gaon Mera Gaurav program, through tribal subplan scheme and SC SP program are promising approaches for enhancement of farmers income.

Although rice is grown in the kharif (roughly July-December), rice is also grown in the rabi (roughly January-June) in many states of India. Approximately 55\% of India's rice crop is irrigated, up from about $45 \%$ in 1990; the fraction of rice area that is irrigated varies by state from <50\% irrigated in Madhya Pradesh, Maharashtra, and Bihar, to $>90 \%$ in Punjab, Tamil Nadu, Andhra Pradesh, and Haryana (Mangal Deep et al., 2018). The decadal changes in the cropping systems research, further to quantify and reach a future novel research strategy to enhance productivity of rice based cropping systems (Table 1).

Pulses as a candidate crop, contributes immensely towards doubling farmers' income through reducing cost of production, enhancing per unit productivity, efficient marketing networks and successful technology delivery mechanisms by giving emphasis sustainable intensification and crop diversification, climate resilient production technologies backed with strong research outputs in pulses can contribute towards doubling the farmers' income. Chickpea, pigeonpea, urdbean, mungbean, lentil, fieldpea, cowpea and lathyrus are the major pulse crops grown in the country (Singh, 2018).
Three and half decade growth of chickpea in India from 1970-71 to 2015-16 (Singh, 2018)

Short duration varieties (JAKI 9218, JG 14, Rajas, Pusa 547, RVG 202, RVG 203, JGK 1, KAK 2, Shubhra) for horizontal expansion of chickpea in southern states.

Disease resistance varieties against Fusarium wilt (GNG 1581, DCP 92-3, HC 1, KWR 108, JG 16, Digvijay, Gujarat Gram 2, BG 391, BGD 78, Ujjawal, GLK 26155, HK 05-169) and Ascochyta Blight (GNG 469 Himachal Chana 1 and PBG 5)

Heat tolerant varieties (JG 14, JSC 55, JSC 56) for late sown condition and Drought tolerant varieties (RSG 888, Vijay) for rainfed conditions

Extra large-seeded (MNK 1, PKV Kabuli 4-1, Phule G 0517) and large seeded kabuli varieties (Shubhra, Ujjawal, KAK 2, GLK 26155) for export purpose

Improved agronomy through appropriate land configuration, supplementary/life saving irrigation, micro-irrigation, precision tillage, pre- and post-emergence herbicides, cropping system/intercropping, conservation agriculture, and farm mechanization

Machine harvestable (GBM 2, NBeG 47, HC 5) varieties

Conservation of indigenous poultry breed is required for developing suitable poultry varieties for backyard farming. In this gesture, to ensure the availability of improved germplasm at farmers' doorstep Indian Council of Agricultural Research has introduced 'Poultry Seed Project' in 2009 with the objectives of supply of day-old chicks of Vanaraja, Gramapryia and Srinidhi bird along with capacity building, medicinal and other 
inputs to the farmers particularly tribal for augmenting rural poultry production, socioeconomic indexing of the target groups and linking small-scale poultry producers with organized market. Vanaraja and Srinidhi poultry is dual purpose poultry birds developed by Directorate of Poultry Research, Hyderabad for backyard poultry farming in rural and tribal areas for meat and egg purpose, respectively (Singh et al., 2018).

The Rainwater harvesting can be useful for installation in areas with water stress due to drought and arid climate. The installations with on site ground water wells that may require significant energy to use such as deep wells and challenging treatment. Installations striving to increase water resilience by implementing net zero water goals.

ICAR Data Centre and Unified Communication portals to secure institute information and information transmission.

ICAR-Enterprise resource planning (ERP) System to this manage the human resource in information of the council including pay roll, finance and budgeting.

KVK Knowledge Network Portal (http://kvk.icar.gov.in) to share basic information and facilities of KVKs with contingency plans, demonstration schedule, and advisories.

Management System for Post-Graduate Education (MSPGE) enabling academic and elearning modules while also being a repository of academic records

E-Samvad, an online interface of the Council to answer citizens queries.

KRISHI -A knowledge repository portal of digital information pertaining to research experiments, outputs, publications, etc.
E-Krishi Manch, a dedicated portal for farmerscientist interaction.

\section{Role of horticulture sector}

Horticulture has emerged as a core sector of agriculture over the past decade, growing steadily in annual area coverage and output (Sujit Kumar, 2018). In the year 2018-19, horticulture stood at nearly 25.8 million ha and production was at a record 314.67 million tonnes which was $1 \%$ higher than previous year.. By 2022, 6.5 lakh ha of additional area will be brought under horticulture crops through area expansion and 1.75 lakh ha of additional area will be brought under protected cultivation. Horticulture is found as an optimal option for crop diversification in agriculture. The per unit earning capacity of farmers is much higher than in case of food grains and it also addresses environmental concerns. The productivity of vegetables and fruits was noticed 17.96 and 14.81 tonnes per hectare, respectively in India during 2018-19 but this was negligible in case of aromatic crops (1.23 tonnes per hectare) and spices (2.10 tonnes per hectare). Therefore, there is more need to focus on aromatic and ornamental crops and spices in state programme as compared to other commodities.

Productivity growth in fruits and vegetable was meagre $(1.57 \%)$ over the past decade. This is only due to non-availability of quality planting material, dwindling status of natural resources, abundance of resource poor farmers and low adoption of modern technologies. The challenge is to enhance productivity by increasing the factor productivity of all the horticultural production inputs, and at the same time sustaining it by adoption of good practices and precision farming principles. Hence, situation specific crops, varieties and modern technologies should be developed, refined/validated and popularized. High cost of input in horticulture crops, prevalence of 
old and unproductive orchards, unorganized supply chain are the major bottle neck, hence adoption of organic agriculture practices and farming system approach should be promoted for decreasing input cost and ultimately increasing the income. Moreover, rejuvenation of old and senile orchard and organized marketing are also very important for getting remunerative income. Facilitation of microirrigation in horticulture sector is also of prime importance in rainfed areas.

As reported $30 \%$ produce of horticultural crops are being spoiled due to their perishability. So their perishable nature should be judiciously targeted based on assessment of production and availability of market to escape unexpected low prices of produce due to high level of production. Based on a survey, it is found that the major problems faced by horticulture farmers are finance, marketing, labour, storage, maintenance, education etc. Major thrust areas for horticulture development are cluster approach linked with post-harvest management, storage and marketing, market intelligence to promote market led production, quality seeds and planting material, adoption of improved varieties and rejuvenation with improved cultivars, hi-tech horticulture and precision farming, high density plantations, etc.

Diversification of present farming system with horticulture crops, availability of microirrigation, resource use efficiency, increase in cropping density, better agronomic practices, incorporation of improved varieties and technologies, area expansion may be taken under consideration as sources of income growth in horticulture sector. Popularization of hybrids may be proved as prompt effort for increasing the income. The hybrid technology has capacity to revolutionise the production of vegetable and ornamental crops and demand for hybrid seeds is continuously increasing. At present, the area under vegetable hybrids accounts for 10 per cent of the total area. High production, earliness, superior quality, uniform produce and resistance to biotic and abiotic stresses are the main advantages of $F_{1}$ hybrids. Adoption of hybrid varieties can increase 1.5-3 times more yields which mean more income from increased output from same area.

In fruit crops, appropriately selected rootstocks have potential to modify the architecture of plants for efficient utilisation of resources. It can develop strong root systems, ameliorate the soil, enhance nutrient and water use. Therefore, rootstocks have become integrated in the production system of grapes, citrus, apple, peach, almond and many fruit crops for successful production. Genetically dwarf cultivars in mango, banana, papaya, sapota and dwarfing rootstocks in mango, guava, citrus, ber suit high density planting system for accommodating more plants, increasing output and income.

Use of CMS line is commercially viable for hybrid seed production in vegetables and floriculture. Use of good quality seed and planting material is a prerequisite for the production of high yields. High quality seeds and planting material help to increase horticultural productivity; improve food security; and imports and raise domestic economic activity. Various diagnostic methods viz. ELISA, Polymerase Chain Reaction (PCR), multiplex PCR, Real Time PCR are available for different viruses, bacteria and fungi in order to enhance the production with diverse disease escaping practices. Technologies for high density planting, canopy management and rejuvenation of old and senile orchards have been developed and successfully demonstrated at farmers' field.

Precision farming application of fertilizers has proved to be profitable along with 
recommendations based on a package of practices. Protected cultivation is a good option for producing quality produce and efficient use of land and other resources in some horticultural crops. It is effective for nursery raising and cultivation of high value vegetables and flowers. Among various irrigation methods, drip irrigation has proved successful in exhibiting high water productivity by saving irrigation water from 25 to 60 per cent in various orchard crops and vegetables with a 10 to 60 per cent increase in yield as compared to the conventional method of irrigation. It is one of the latest methods of irrigation which is becoming popular in areas with water scarcity and salt problems. Adoption of micro-irrigation can save input costs to the farmer is estimated in the range of 20 to 40 per cent in case of horticultural crops. The cultivation of horticultural crops is labour intensive and it needs timely operations for maximising the production. The end to end mechanisation of the horticultural crops is required to be adopted. Several implements and machines have been developed to enhance the efficiency of farm operation in high tech nursery, precision farming, high density plantation, protected cultivation, etc.

Bio-fertilizers are microbial preparations containing living cells of different microorganisms which have the capacity to mobilize plant nutrients in soil from unsoluble to soluble form through biological process. Streamlining is required in the use of biofertilizers, VAM fungi, biological $\mathrm{N}$ fixers and other beneficial microbial agents for effective nutrient use efficiency. Nano- encapsulated conventional fertilizers, pesticides and herbicides helps in slow and sustained release of nutrients and agrochemicals resulting in precise dosage to the plants.

Horticulture based cropping system optimises use of the space and time and improves upon productivity from same piece of land. This has an income doubling impact for farmers. Promotion of Integrated farming system approach involving synergic blending of crops, horticulture, dairy, fisheries, poultry, etc. seems viable option to provide regular income and at site employment to small land holder, decreasing cultivation cost through multiple use of resources and providing much needed resilience for predicted climate change scenario. At present the cropping intensity in agriculture as a whole is 138.9 per cent, and segregated statistic is not available for horticultural crops. Any increase in the intensity would add to the production from farms accordingly. Higher cropping intensity is made possible with various measures, primarily irrigation, use of fertilizers, crop rotation, mixed cropping, relay cropping, etc. In perennial horticultural crops, the brown space available in the prebearing age of the orchard can be effectively utilised to grow short duration horticultural crops like pulses, spices, vegetables as intercropping or for interspaced planting and cultivation to gain higher income.

Mechanical tools, tiller tractors, sowing gadgets, etc. can save critical time between crops thus enabling use of short duration crops or fast maturing varieties. There remains a considerable gap between the gross production and net availability of fruits and vegetables due to heavy post-harvest losses in case of horticultural produce. It is estimated that India incurs postharvest fruits and vegetable losses worth over two lakh cores each year largely owing to the absence of modern cold storage facilities and lack of proper food processing units. More emphasis needs to be given to post-harvest management of fruits and vegetables. Besides storage and processing, the cold-chain is seen as a value adding activity as it allows farmers to capture greater value. Commercial floriculture has been steadily increasing with increased use of protected cultivation employing greenhouse, 
shade nets, polyhouse, etc. Commercial flowers cultivation in India provides an opportunity for rural development owing to its higher returns per unit area and the new employment opportunities. Nearly eighty per cent of area under floricultural crops is concentrated in seven states comprising Tamil Nadu, Karnataka, Andhra Pradesh, West Bengal, Maharashtra, Haryana, Uttar Pradesh and Delhi. A major part of the area under flower cultivation is devoted to the production of Marigold, Jasmine, Rose, Chrysanthemum, Tuberose, etc., with considerable increase in the area under cut flower cultivation. Share of Uttar Pradesh in floriculture is only 5\% which is at near bottom as compared to other states of country even very small states like Karnataka, Tamil Nadu are far ahead (>10\%).

Therefore, this sector can be identified as grey area which can be directly included in different farming systems as a viable diversification from the traditional field crops because of higher returns.

Spices sector is one of the most vibrant sectors of the Indian agricultural trade. The share of spices in the total agricultural export works out to about 6 per cent annually. The world demand for organic spices is growing rapidly in developed countries like Europe, USA, Japan and Australia. India has a greater potential to encash this trend by diversifying into high-value crops like saffron, cardamom, turmeric, chillies, ginger and vanilla beans.

The demand for organic fruits and vegetables is increasing at a rapid pace. Such horticultural produce grown through organic means is nutritionally superior and free from the injurious pesticide residues. The protocol for organic production in many horticultural crops has been worked out which includes a use of resistant varieties, management of soil vermicompost and bio-fertilizer, and management of disease and pests using biological control as well as bio-pesticides. Recently Sikkim has been announced as hundred per cent organic cultivation state.

The country has a vast production base which offers growth opportunities for export. Mangoes, walnuts, grapes, bananas, pomegranates account for larger portion of fruits exported from the country while onions, okra, bitter gourd, green chillies, mushrooms and potatoes contribute largely to the vegetable export basket. The major destinations for Indian fruits and vegetables are UAE, Bangladesh, Malaysia, Netherland, Sri Lanka, Nepal, UK, Saudi Arabia, Pakistan and Qatar. Floricultural exports from India comprise of fresh cut flowers (to Europe, Japan, Australia, Middle East and USA), loose flowers (for expatriate Indians in the Gulf), cut foliage (to Europe), dry flowers (To USA, Europe, Japan, Australia, Far East and Russia), potted plants (limited to Middle East) besides seeds and planting material. Among fruits mango, guava, banana, papaya, aonla, bael, vegetables okra, onion, potato, cabbage, watermelon, flowers like rose, tuberose, gladiolus, marigold and medicinal and aromatic plants such as artemisia, mentha, citronella, ashwagandha, palmarosa, brahmi, basil, damask rose, vetiver, lavender, are the potential crops. Standard of these crops may be validated/refined for export parameters in which APEDA and Directorate of Agriculture Marketing and Foreign Trade play a key role.

Agroforestry conserves natural resources through various systems under different agro climatic regions. Millions of farmers are dependent on agroforestry farming systems as a way of increasing and sustaining agricultural productivity, as a source of essential food, fuel wood, fodder and building materials and as a supplementary source of income. In North India farming system based on agri-silvi pasture, horti-silvi pasture and other agroforestry modules can be popularised to 
enhance the farmers' income. Quality seeds play significant role in the agriculture production. Farmers can enhance their income through participatory hybrid seed production programme for different seed companies. It is a form of contract farming where farmers are supplied with inbred lines for further crossing and production of hybrid seeds of vegetable crops. Hybrid seed production and other open pollinated seed production including planting material of vegetable crops, floriculture and fruit plants is the potential sector for prompt enhancement in farmers' income. Hence, this sector should be promoted in PPP mode. The productivity of horticultural crops like fruits, vegetables, flowers, plantation crops and spice crops can be increased by supply of disease free quality planting material to farmers. Beekeeping is an agro-based activity which is being undertaken by farmers/landless labours in rural area as an integrated farming practice.

In various agricultural and horticultural crops, honey bees' pollination also improves the quality of produce. Honeybees, in addition to enhancing the yield of various crops also convert nectar and pollen into honey and other beehive products, viz. bees was, royal jelly, propolis, etc. which provides additional income to the farmers/beekeepers. Mushroom cultivation can also represent a valuable small scale enterprise option. Surplus crop residues which are being burnt in the country and becoming a threat for ecology should be utilised for casing preparation in mushroom production as example of $10 \%$ surplus provided significant gain in mushroom production. Urban and peri-urban horticulture needs to be promoted as one of the facets that will keep cities clean, as it has highest potential to reutilise recycled water and solid waste (compost) for gainful purposes. Tomato, potato and onion are the most sensitive crops to price fluctuations form almost 50 per cent of the total fruit and vegetable sales. The prices of tomato, onion and potato fluctuates owing to disparity between demand and supply fuelled by the clash of interests between the consumer, the producer and the middlemen on account of a drop in production because of unfavourable weather, a rise in transport costs, seasonality and supply chain constraints. To reduce price fluctuations, a complementary storage option to be developed to locate buffers of onion and potato close to the markets. These need not be high technology systems but designed to cater to a two week inventory cycle from the buffer into market. All efforts to increase potato production must be balanced with developing external demand and hence export trade needs to be promoted if pursuing future growth in production. A favourable trade policy for potato will favour higher production and productivity and also promote growth in coldchain. Potato seed production at present is being taken up only in a few states like Punjab, Haryana and Uttar Pradesh. The seeds produced in these states are supplied to other producing states of the country. Seed production in states like Karnataka, Madhya Pradesh, Gujarat and Odisha can be promoted, so that the farmers of these states may get quality seed at reasonable prices. Protected cultivation of tomato and other high value vegetables and ornamentals needs to be promoted in different peri-urban areas, to meet the demand during lean period, i.e., from July to October. Area expansion programme for kharif and late kharif onion can to be taken up in non-traditional states like Madhya Pradesh, Rajasthan, Haryana, Bihar, Odisha and Gujarat to avoid the pressure on Maharashtra, Karnataka, Andhra Pradesh etc. during lean period i.e., July to March. Onion seed production is presently being undertaken by traders in the states of Maharashtra, Gujarat and some part of Madhya Pradesh, to supply the seed all over the country. Suitable seed producing pockets in other state like Rajasthan, Punjab, Bihar and Odisha can be developed so that there is more availability of 
seed at reasonable price across the country. Onion storage capacity is required to be enhanced in the states of Madhya Pradesh, Rajasthan, Gujarat, Uttar Pradesh, Bihar, Odisha, etc. to cater the needs of north and north eastern regions of the country.

Integrated Farming Systems aim to increase production, income and to improve nutrition of small scale farmers with available resources.

Components of farming system includes all types of crops like field crops, horticultural trees, animals (cattle, buffalo, pig, goats, sheep, fish), sericulture, apiculture, mushroom cultivation, forage crops, flowers and vegetable cultivation, biogas production and non-conventional plant resources (Munda et al., 2007).

An effective farming system includes the cropping system(s), the livestock system(s) and the farm household. Diversified farming system increases productivity, profitability, balanced food ratio, adoption of new technology; solves energy, fodder, fuel and timber crisis; avoids degradation of forests and environmental pollution, generates employment and provides opportunities for Agro-industries by utilizing the natural resources efficiently and this will help in maintaining sustainability.

In North Eastern region, native farming system models like shifting cultivation, bun system, rice cum fish culture, bamboo drip irrigation, alder based agriculture and zabo system, dairy, pig, poultry and fishery based farming systems are quite effective for enhancement of farmers income (De and Singh, 2017).

Suitable land use systems such as Agrihorti (growing of two third area with horticultural crops and one third area with cereals), Agri- horti-silvi pastoral (growing of one third area with horticultural crops, one third area with fodder trees and rest one third area with cereals and fodder grasses), mixed horti (growing of two third area with horticultural crops and one third area with vegetable crops), pure horti (growing fruit crops only), hortisilvi-pastoral (growing of fruits, vegetables, fodders, fuel wood, timber), and multi-tier horticulture system (growing of horticultural crops of different heights viz. arecanut + black pepper + ginger or turmeric) should be developed based on agroclimate zones, crop priority, topography and socio-economical factors (Purohit and Gehlot, 2006).

\section{General strategy for improving farmers' income}

The Hon'ble Prime Minister of India, Narendra Modiji suggested a multidimensional seven point strategy which includes:

More crop per drop using micro irrigation practices and nutrient film techniques

Production of quality seeds and nutrient supply according to the soil quality to each farm through referring soil health cards.

Large investment for creation of cold chain and warehouses to prevent post-harvest losses.

Promotion of value addition though processed food, storage, pack house, referral van, ripening chamber, warehouses, cold chain \& marketing, etc

Create marketing facilities for getting best recovery price of produce through implementation of e-NAM, formation of FPO/Farmers' Co-operative Societies, more marketing channels (PS UP), market-oriented variety wise cultivation (by $\mathrm{J} \& \mathrm{~K}$ ), assured price scheme (by AP), effective procurement 
strategies to procure on MSP (Rajasthan), trading policies should be farmer-oriented, not trader, price-deficit financing scheme by M.P.

Introduction of crop insurance scheme like Pradhan Mantri Fasal Bima Yojna at low cost to mitigate the risk.

Promotion of agriculture allied activities Dairy, Animal husbandry, Poultry, Bee Keeping, Horticulture and Fisheries.

Horticultural Strategies for Doubling of Farmers Income for Different AgroClimatic Zone (Gautam et al., 2018)

\section{Establishment of new orchard}

High density planting in Mango, banana, papaya, guava, Citrus, Litchi, Peach, Ber, Jackfruit, Lemon.

Multi-tier cropping system in problematic soil: Aonla, bael-ber, guava-karoda/ phalsa Pomegranate, Citrus, Custard apple.

Establishment of orchard: bael, ber, jackfruit, jamun mahua, Litchi, Kinnow, Guava, Citrus, Pomegranate.

Inter cropping of leguminous vegetables, cucurbits, seed spices, Arvi, Onion, Garlic, Chilli, Tomato, Tuber crops.

Promotion of gyno-dioecious cultivars of papaya.

Management of old and unproductive orchards in citrus, litchi mango, guava through

Rejuvenation

Window opening in mango

Canopy management in other fruit crop
Inter cropping of leguminous vegetables, cucurbits, seed spices, Tomato, chilli, cole crops, Tuber crops

Promotion of inter cropping - Turmeric, Elephant foot yam, (Suran)/ Colocasia (Arvi), Ginger

\section{Hi-tech horticulture nursery management technologies}

Standardization of root stock in apple, mango, guava, Kinnow, Custard Apple, Citrus, Litchi, Peach, Ber, Jackfruit, Lemon, almond, sapota

Establishment of mother block on newly released variety of fruit crops viz. Mango, guava, aonla, bael, ber, citrus, Custard apple, Pomegranate.

Use of nursery growing structures viz. mist chamber, net house, etc.

\section{Production technology of tissue culture banana by}

Establishment of tissue culture laboratory

Entrepreneurship development through hardening and supply of saplings of tissue culture banana

Double row planting system of banana

Inter cropping of off season vegetable crops in banana

\section{Improved production technology of} vegetable crops

Commercial nursery production

Off \& on season vegetable production technology viz. Cucurbits, cole crops, okra, cow pea, tomato brinjal, chilli, moringa, vegetable pea, Potato, Ash Gourd, Onion, 
Garlic, Water Chest nut, Moringa, Carrot, Radish, Leafy vegetables Cauliflower, Cabbage.

Vegetable production under protected condition viz. high value low volume crops (capsicum, cucumber and exotic vegetables) in peri-urban areas

Technologies for promotion of secondary horticulture in peri urban areas

Value addition

Seed production technology of vegetable crops viz. vegetable pea, cow pea, Cole crops, cucurbits, tuber crops, Potato, Ash Gourd, Okra, Broad bean, Guar, Chilli, tomato, brinjal, root crops.

Production of Water chest nut

\section{Flower production}

Commercial nursery production

Cut flowers/ house plants/ ornamental plants production under protected cultivation in peri metro areas viz. gerbera, rose, etc.

Cut flowers cultivation in peri metro areas viz. rose, tuberose, gladiolus, lily, orchids, chrysanthemum, anthurium, gerbera, aster

Production of loose flowers in peri spiritual cities viz. rose, marigold, jasmine, bela etc. Chandani, Hibiscus, Gailardia, crossandra

Value addition

Production of medicinal, aromatic and spices

Commercial nursery production.

Cultivation technology viz. mentha, satavar, lemon grass, Artimicia,, Aloe vera, Ashwagandha, Sarpgandha, Vinca, Basil, Shankhpushpi, Acorus, Opium, Stevia, Tulsi.

Waste land development through cultivation of M\&AP viz. Aloe vera, ashwagandha, sarpgandha, Citronella, Lemongrass, Khas, Artimicia, Geranium, Kewda, Acorus, Water chest nut.

Establishment of horti-medicinal-aromatic cropping system in waste land

Establishment of agro-forestry system/ bamboo production in waste land

Value addition and small scale industry

Table.1 Rice based cropping systems

\begin{tabular}{|c|c|c|c|}
\hline Sl.No. & Irrigated conditions & Upland conditions & $\begin{array}{c}\text { Rice under integrated } \\
\text { farming systems }\end{array}$ \\
\hline $\mathbf{1 .}$ & Rice-Rice-Rice & Rice-Chick pea & Rice-Fish-Poultry \\
\hline $\mathbf{2 .}$ & Rice-Rice-Cereal & Rice- Lentil & Rice-Fish-Duckery \\
\hline $\mathbf{3 .}$ & Rice-Rice-Pulses & Rice-Mustard/Linseed & \\
\hline $\mathbf{4}$ & Rice-Wheat-Pulse & Rice-Barley & \\
\hline $\mathbf{5 .}$ & Rice-Toria-Wheat & Rice-Wheat & \\
\hline $\mathbf{6 .}$ & Rice-Mustard & & \\
\hline
\end{tabular}

Source: Mangal Deep et al, 2018 
Resource conservation technologies for enhancing production of horticultural crops

Micro-irrigation system

Rain water harvesting

Mulching

Farm mechanization

Recycling of farm/ processing industry waste

Role of ICT in doubling income of farmer through horticultural crops

\section{References}

Chand, R. 2017. Doubling Farmers IncomeRationale, Strategy, Prospects and Action Plan. Niti Policy Paper No.1/2017, National Institution of Transforming India, New Delhi, pp.40.

De, L.C. and Singh, D.R. 2017. Natural resources in North East region of India. International Journal of Agricultural Science and Research, 7(5): 51-66.

Gangaiah, B. 2018. Challenges and opportunity for Indian Agriculture. $3^{\text {rd }}$ International Conference on Agriculture and Horticulture, 2168.

Gautam, U.S., Singh, Anand, Shahi, B.P., Singh, Maneesh Kumar and Srivastava, D.S. 2018. Strategies for dubling farmers income through horticulture based interventions in different agroclimatic zones of Uttar Pradesh. International Journal of Agriculture Sciences, 10 (14): 67126715.

Kumar, Sujit. 2018. Doubling farmers income with production enhancement through productivity gains. Journal of Pharmacognosy and Phytochemistry, 7(1): 1904-1909.

Mangal Deep, Kumar, R.M., Saha, Soumya and Singh, Aarti. 2018. Rice based cropping systems for enhancing productivity of food grains in India. Indian Farming, 68 (01): 27-30.

Munda G.C., Ghosh P.K., Das A., Ngachan S.V., and Bujarbaruah K.M., 2007. Advances in Organic Farming Technology in India, Director, ICAR Research Complex for NEH Region, Umiam-793103, Meghalaya, pp.585

Purohit, S.S. and Gehlot, D.2006. In 'Trends in Organic Farming', Agrobio India, Jodhpur Rajasthan.

Saikia, D. and Bordoloi, R. 2019. Strategic interventions on horticultural sector for doubling farmers income in Assam by 2022-23. Acta Scientific Agriculture, 3 (1): 56-58.

Singh, N.P.2018. Pulses as candidate crops for doubling Farmers income. Indian Farming, 68(01): 36-43.

Singh, Mahak, Mollier, R.T., Rajesha, G., Nguillie, A.M., Rajkhowa, D.J., Rajkumar, U., Paswan, Chandan and Chatterjee, R.N. 2018. Bacyard poultry farming with Vanaraja and Srinidhi. Indian Farming, 68 (01): 80-82.

\section{How to cite this article:}

De, L. C., Tulipa De, R. K. Pamarthi and Singh, R. K. 2019. Agri-Horticultural Interventions for Doubling of Farmer's Income. Int.J.Curr.Microbiol.App.Sci. 8(12): 1414-1425. doi: https://doi.org/10.20546/ijcmas.2019.812.171 